\title{
Application of islamic law in the Uk and universal human rights
}

\author{
Manea, Elham
}

\begin{abstract}
Should Islamic Law be introduced into Western legal system? At the heart of the issue is a debate on legal pluralism, which envisions a society where different laws apply to different religious groups. This paper explores question using the British case of Sharia Councils. Building on the author's knowledge of the situation of women in Middle Eastern and Islamic countries, she undertook firsthand analysis of the Islamic Sharia councils and Muslim arbitration tribunals in various British cities. She offers a pointed critique of legal pluralism, highlighting the type of Islamic law being used and its human rights ramifications.
\end{abstract}

DOI: https://doi.org/10.15366/reim2020.29.006

Other titles: Derecho humanos y aplicación de la ley islámica en el Reino Unido

Posted at the Zurich Open Repository and Archive, University of Zurich

ZORA URL: https://doi.org/10.5167/uzh-200548

Journal Article

Published Version

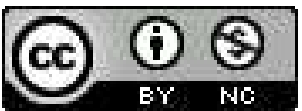

The following work is licensed under a Creative Commons: Attribution-NonCommercial 4.0 International (CC BY-NC 4.0) License.

Originally published at:

Manea, Elham (2020). Application of islamic law in the Uk and universal human rights. Revista de Estudios Internacionales Mediterráneos, (29):72-87.

DOI: https://doi.org/10.15366/reim2020.29.006 


\title{
Application of Islamic Law in the UK and Universal Human Rights \\ Derechos Humanos y aplicación de la ley islámica en el Reino Unido
}

Elham MANEA ${ }^{1}$

Political Science Institute, University of Zurich

manea@pw.uzh.ch

http://orcid.org/0000-0002-9825-4433

Recibido: 15/07/2020. Revisado y aceptado para publicación: 27/11/2020

Para citar este artículo: Elham MANEA (2020): "Application of Islamic Law in the UK and Universal Human Rights" en Revista de Estudios Internacionales Mediterráneos, 29, pp. 72-87.

Para acceder a este artículo: https://doi.org/10.15366/reim2020.29.006

\begin{abstract}
Should Islamic Law be introduced into Western legal system? At the heart of the issue is a debate on legal pluralism, which envisions a society where different laws apply to different religious groups. This paper explores question using the British case of Sharia Councils. Building on the author's knowledge of the situation of women in Middle Eastern and Islamic countries, she undertook firsthand analysis of the Islamic Sharia councils and Muslim arbitration tribunals in various British cities. She offers a pointed critique of legal pluralism, highlighting the type of Islamic law being used and its human rights ramifications.
\end{abstract}

Keywords: Pluralism/Islamic Law/Human Rights/Women's rights/British sharia councils/Muslim arbitration tribunals/

\section{Resumen}

¿Debería introducirse la ley islámica en el sistema legal occidental? En el fondo de esta cuestión está el debate sobre la pluralidad de legislaciones, que implica la existencia de diferentes leyes que se aplican a diferentes grupos de una misma sociedad. Este artículo examina la cuestión sirviéndose del caso de los Tribunales de Sharía británicos. A partir del conocimiento de primera mano de la situación de las mujeres originarias de Oriente Próximo y los países islámicos, se analizan los Tribunales de Sharía Islámica y los tribunales musulmanes de arbitraje de varias

\footnotetext{
${ }^{1}$ This paper presents a segment of the results of her book published in 2016 with the title Women and Sharia Law: The Impact of Legal Pluralism in the UK, London, I.B. Tauris. In the book the experience of British Muslim Women and their diverse campaigns to end the application of Islamic Law was duly documented.
} 
ciudades británicas. Se ofrece una crítica detallada de este pluralismo legislativo, descubriendo el tipo de ley islámica utilizada y sus ramificaciones en lo relativo a los derechos humanos.

Palabras clave: Pluralismo Jurídico/Ley Islámica/ Derechos Humanos/ Derechos de las Mujeres/ Tribunales de Sharía Británicos/

\section{Introduction}

The United Kingdom allows the application of Islamic law in family affairs in Sharia councils and Muslim arbitration tribunals. Muslims are not the only group that resort to their religious laws. Jewish and Hindu laws are also used as well. My research however focuses on the Muslim separate legal system that exists.

Application of Islamic Law takes two forms, in the Sharia Councils and in the Muslim Arbitration Councils. The number of Sharia Councils is unknown and ranges from 35 to 85 councils. ${ }^{2}$ These are not subject to any supervision, they deny access to legal advice and legal assistance, appeals to their decisions are not possible and their focus is on family disputes. The majority of their applicants are women, who seek a religious divorce from their husbands. Muslim Arbitration Tribunals apply Islamic Law under the British Arbitration Act of 1996 and therefore their judgments are legally binding. Both parties must agree first to arbitration. There are indications that these tribunals, just like the councils, have turned into parallel Legal structures. They arbitrate on family disputes, domestic violence and even in cases of child abuse (Manea: 2016).

Within the United Kingdom's context, three general groups have been calling for the introduction of forms of Islamic law, shari'a, into British legal system:

- Islamic and Islamist organisations. The terms Islamic and Islamist have different meanings. Islamic organisations often represent a traditional if not conservative reading of Islam, are led by individuals of traditional/conservative religious background, and often seek to impose a religious identity on 'Muslim community' members. Islamist organisations espouse a political agenda that aims to Islamise migrant communities of Islamic faith. Some Islamic organisations have members who espouse the ideology of Islamism and some do not. Often they work together and support each other's religious demands. Together they often claim to be the sole representative and voice of 'Muslim communities' and their experts on their 'needs'.

- High officials, lawyers, judges or political personalities, who seem to be concerned about how Muslim communities are becoming integrated in their respective countries, and consider the move toward shari'a law inevitable if Muslims are to integrate 'successfully'. Dr Rowan Williams, the former archbishop of Canterbury, is one famous example; another is Marion Boyd, Ontario's attorney general. Some of these people may be calling for soft legal pluralism for pragmatic political reasons. They earnestly believe that combating Islamic extremism - a serious problem in Britain - will require giving small concessions to the Muslim community, such as allowing them to live by Islamic family laws. Britain's former Lord Chief Justice Baron Phillips of Worth Matravers (equivalent to the chief justice of the US Supreme Court) made a comment that might be understood in this light. It is no coincidence that Islamic and Islamist

\footnotetext{
${ }^{2}$ For more information on the work of Sharia Councils See Bano, Samia (2012), Muslim Women and Shari'ah Councils: Transcending the Boundaries of Community and Law, London, Palgrave Macmillan.
} 
organisations in Britain make the same argument: "Give us Islamic law in family affairs to curb extremism" (Brown: 2006).

- Academics in a range of social science fields, specifically legal anthropology, law and sociology, who are leading a theoretical and intellectual discourse on legal pluralism. Legal pluralism was defined by Jacques Vanderlinden in 1972 as "the existence within particular society of different legal mechanisms applying to identical institutions" (Woodman, 1999: 4). Simply said, it is a system that allows religious, ethnic and cultural groups to apply their own laws within the state. Scholars make a distinction between two forms of legal pluralism, strong and week. ${ }^{3}$ Yüksel Sezgin explains that weak legal pluralism occurs when the state "commands different bodies of law for different groups in the population by incorporating their normative orderings into the central administration of law and courts (Yüksel Sezgin, 2004: 102). Strong legal pluralism, on the other hand, exists when "State law is just one among many other normative orderings in society" (ibid).

The debate on legal pluralism often revolves around the question: does the state have a monopoly on legal productions and norms, on minorities and multiculturalism? They maintain that legal centralism is a Western model of jurisprudence, that it ignores the experience of non-Western nations. They blame colonial powers for depriving people in developing countries of access to their own traditional and customary laws, imposing their version of positive law on their colonies. They cite a "more complex" relationship between law and society, one "where law is conceptualised as more plural, not located entirely in the state" (Yilmaz, 2005: 2).

Accordingly, legal pluralists hold that state law is only one of many levels of law; their idea implies a plurality of social fields and producers of norms, which interact somewhat with each other. They also insist that legal pluralism is an adequate system that guarantees the protection of minorities' rights and of their entitlement to be different. ${ }^{4}$ They insist that an even-handed sensitivity to difference requires an abandonment of the formal vision of equality, one that assumes that all citizens are inherently identical. Instead, the legal system should take cognizance of the identity and values of different sections of the population, no matter how distinctive these values maybe (Grillo et al, 2009: 25-26). Within the British discourse on weak legal pluralism, some strong advocates are the American John R. Bowen, mentioned above, who is Dunbar-Van Cleve Professor in Sociocultural Anthropology at Washington University in St. Louis, Roger Ballard, the Director of the Centre for Applied South Asian Studies, and Tariq Modood, a British-Pakistani professor of sociology, politics and public policy at the University of Bristol.

Members of these three groups are often of the opinion that weak legal pluralism is just one out of many instruments for resolving conflicts, and that it is an extension of a right already given to the Jewish minority: a right to arbitration tribunals in a system called Beth Din. And, they say, since the Jews already have it, why not Muslims as well?

They emphasise that this instrument of conflict resolution is voluntary, that they only support it with safeguards that ensure respect for human rights, especially for women's rights. Accordingly, if a member of a religious minority does not want to be ruled by these laws, all she or he has to do is to opt out and leave the community.

And they often argue that the Western legal tradition, which is based on legal centralism and state monopoly over legal productions and a monistic conception of law (the basic foundation on which

\footnotetext{
${ }^{3}$ The first who introduced the binary distinction between strong and weak legal pluralism was Griffiths, John in 1986.

${ }^{4}$ See Grillo, Ralph et al (eds) (2009), Legal Practice and Cultural Diversity, Surrey, Ashgate; Griffiths, John (1986): "What is Legal Pluralism?", Journal of Legal Pluralism, vol. 32, nr. 24; Ihsan Yilmaz (April 2002): "The challenge of postmodern legality and Muslim legal pluralism in England", Journal of Ethnic and Migration Studies xxvii/2; Dupret, Baudoiun; Berger, Maurits Berger and al-Zwaini, Laila (eds) (1999), Legal Pluralism in the Arab World, The Hague, Kluwer Law International; Kemper, Michael and Reinkowski, Maurus (eds) (2005), Rechtspluralismus in der islamischen Welt: Gewohnheitsrecht zwischen Staat und Gesellschaft, Berlin, Walter de Gruyter.
} 
liberal-democratic nations are instituted) is Euro-American centric and ignores the experience of non-Western nations.

Those calling for soft legal pluralism in the UK are often shaped by strong or weak cultural relativism. The strong cultural relativists hold that "culture is the principal source of the validity of a moral right or rule [...] the presumption is that rights (and other social practices, values, and moral rules) are culturally determined" (Donnelly, 1984: 401). The weak cultural relativists, on the other hand, assert that "culture may be an important source of the validity of a moral right or rule. Universality is initially presumed, but the relativity of human nature, communities, and rights serves as a check on potential excesses of universalism" (Donnelly, 1984: 401).

Absent from this plead for the introduction of Islamic law is the actual experience with legal pluralism in non-Western countries specifically with its often grave political and human rights consequences. Also absent is clarity about the type of Islamic law being used in this so-called method of conflict resolution. No one considers the social context within which this law is being implemented. The diversity and multitude of positions towards Islamic law, the critical discourse in Islamic countries among civil society actors and intellectuals, and their attempts to change Islamic laws: none of this seems to be relevant to their discourse. Indeed, the discourse is very academic and theoretical, ignoring the settings or circumstances within which women are living in closed societies. It is as if Muslim women, Muslims and Islam itself had been crafted and constructed separate from their historical, political, social and religious contexts.

Also absent from their discourse is an awareness of the role that two forms of Islamism - societal and political - plays in promoting this development, or of their totalitarian agenda.

\section{Islamic Law and Universal Human and Women's Rights}

I tend to avoid using expressions like divine law or God's law to describe shari'a. There are different approaches to defining it. One approach would be similar to the way Ramadan and with him Williams tried to distinguish between shari'a as the 'expression of the universal principles of Islam' and shari'a as fiqh: the 'doctrinal traditions developed by jurists over centuries.' This definition by distinction has a particular purpose: to make space for new interpretations of Islamic law by emphasising the limited authority of the fiqh and to create space for others to contribute to developing norms for fiqh in a changing world. (Emon, 2012: 8-9).

Another approach would avoid defining shari'a in legally philosophical terms and would focus more on studying the sources that are understood to constitute the corpus of shari'a, especially on the work of pre-modern jurists, work which is so central to the study of Islamic law in the twentieth century ${ }^{5}$.

The first approach, while it deserves our applause, ignores how Islamic law is being implemented in reality. It also reinforces the constructed perception that shari'a is indeed God's law, and has

\footnotetext{
${ }^{5}$ Shari-a is derived from four sources: 1 ) the Qur'an, compiled into a written text approximately 30 years after the death of Mohammad; 2) the Sunna, the sayings and deeds of Mohammad, compiled in a written form approximately 200 years after his death; 3) ljma, the consensus of legal jurists on an issue; and 4) Qiyas, analogy: "a jurist concluding from a given principle embodied in a precedent that a new case falls under this principle or is similar to this precedent on the strength of a common essential feature called the reason". Qiyas is often considered similar to ijtihad, defined as independent juristic reasoning and a technique for such reasoning. However, the gates of ijtihad were supposed to have been closed after the ninth century. For more information please see An-Na'im, 1990: 19-25.
} 
thus far failed to acknowledge the limits of religious interpretations. Put simply, trying to avoid acknowledging the human nature of religious texts, including the Qur'an, makes any attempts at reform futile and holds those texts captive within specific religious boundaries. In addition, we must recognise the historical nature of many Quranic verses, like those that see wife-beating as a disciplinary action, or that allow a man to have female slaves in addition to four wives, or to kill 'unbelievers', or to engage in corporal punishment. And we must also state clearly that these interpretations can no longer be seen as appropriate in a modern society. Unless the advocates of this approach recognise these differences, such an approach will be both superficial and ad hoc and will fail to address the problems inherent in the legal side of Islam.

The approach I adopt here, which is closer to the second one mentioned above, defines shari'a by the way it is being implemented in Islamic states and within Muslim family laws. I see it as a selection from the corpus of legal opinions of jurists developed over the course of Islamic history, especially between the seventh and tenth centuries.

Looking at shari'a from this perspective will highlight its problematic nature, for we are not considering its theoretical potential to provide justice. What we are in fact looking at is its actual implementation and hence its obvious limitations and how it contravenes modern concepts of human rights. What matters is how it is being interpreted and used today, not how it could be used a century from now.

I deliberately used the word modern above, because - let me repeat - the jurisprudence suggested and under consideration was developed between the seventh and tenth centuries. This historical period, early in the development of Islam as a whole, shaped its content and its perception of women's role in society, and is reflected in its worldview of what constitutes a human and who can enjoy human rights.

In fact, if we look at the actual corpus of Islamic law, human rights can be defined as the privilege "only of persons of full legal capacity". A person of full legal capacity is "a living human being of mature age, free [not a slave], and of Moslem faith". Under this definition, others who lived in the Islamic state, including non-Moslems and slaves, were "only partially protected by law or had no legal capacity at all" (Khadduri, 1946: 79). This definition was formulated in 1946 by Majid Khadduri, an Iraqi-born American academic recognised as a leading authority on Islamic law and the modern political history of the Middle East.

More than fifty years later, that definition was qualified by Abdullahi Ahmed An-Na'im, a leading Sudan-born American authority on Islamic law and human rights. In 1990, he accepted Khadurri's statement as "substantially accurate" and added a qualification concerning the status of Muslim women. He acknowledged that Muslim women "have full legal capacity under Shari'a in relation to civil and commercial law matters", but they "do not enjoy human rights on an equal footing with Muslim men under Shari'a” (An-Na'im, 1990: 171).

\section{What does that mean?}

It means that in addition to creating a stratified citizenry dominated by free male Muslims, the way shari'a dealt with the status of women was often contradictory, offering women some rights but withholding many others, while maintaining the notion that the Muslim man is the keeper and guardian of the Muslim woman.

In general, one can discern two levels of statements in the Qur'an regarding women's status. The first level treats women and men as equal before God - that is, in the afterlife. For example, one verse states 'Whoso does evil will be requited only with the like of it; but whoso does good, whether male or female, and is a believer - these will enter the paradise; they will be provided therein without measure.' (Qur'an 40:41) 
Qur'anic verses at the second level place women at a legal disadvantage. These are the statements on issues of family and sexual relations, rules of marriage, divorce, custody, maintenance, inheritance and testimony - that is, rights within this life. On these issues, Qur'anic verses reflect the social tribal patriarchal context of the seventh-century Arabian Peninsula, specifically the city of Medina. They favoured men and accorded women a lower and dependent legal status. From this we see the clear inconsistencies on the status of women between the Qur'anic provisions and the modern statements on human rights, such as the 1948 Universal Declaration of Human Rights (UDHR) and the Convention on the Elimination of All Forms of Discrimination against Women (CEDAW).

Let us start with the first part of An-Na'im's qualification. He says that under shari'a, a Muslim woman has full legal capacity in relation to matters of civil and commercial law. This means that she can own property as a separate person and that when she marries she can keep her name. Hence when I married, I kept my family name, Manea, and did not take my husband's name. Nor did he take over whatever property I had. It remained in my possession. From this perspective, a Muslim woman is treated as an individual.

Yet An-Na'im is also correct to state that, under shari'a, Muslim women do not enjoy human rights on an equal footing with Muslim men. In fact shari'a laws contravene various provisions of human rights conventions, specifically the UDHR and the CEDAW mentioned above.

Human rights conventions are clear in their statements about the equality of man and woman. The essence of their worldview is expressed by Article One of the 1948 UDHR: that all human beings are born free and equal in dignity and rights. This principle paved the ground for Article 16 of the same declaration and Article 16 of CEDAW. Both articles envisioned marriage and family relations as an equal partnership that would be entered, shared and dissolved by both man and woman on equal footing. Marriage should be entered by two persons of full age, with their free and full consent, without any limitation due to race, nationality or religion. The spouses should have same rights and responsibilities with regard to guardianship of children, and the same personal rights as husband and wife, including the right to choose a family name, a profession and an occupation. And both spouses should have the same rights in respect of the ownership, acquisition, management, administration, enjoyment and disposition of property, whether free of charge or for a valuable consideration.

This is not the case in the world view of classical Islamic law: woman is part of a hierarchical social structure dominated by the man at the top; and as a legal person the woman is controlled before her marriage by her male guardian and after marriage by her husband.

The rules regarding marriageable age and guardianship make child marriages and forced marriages possible, and rules on divorce and maintenance rights discriminate against the wife.

In fact, the Islamic law's view towards the position of the wife within marriage can be easily discerned by considering the legal term used for marriage - a term, remember, that was developed in the Middle Ages.

In Islamic law, the term for marriage is nikah, which literally means carnal union. Jurists describe nikah as "an agreement, which results in the lawful enjoyment of a woman" (Shukri, 1996: 21). The reference to enjoyment applies only to the husband, because that right belongs especially and pre-eminently to him. In fact, the husband is entitled to intercourse with his wife at his pleasure. On the other hand, two realities restrict the wife's right to enjoyment. First, she has no right to 
claim intercourse with her husband, except for one time after marriage, and second, she may have to share him with other wives (Shukri, 1996: 21).

This perception of marriage is not theoretical. In fact it has been used repeatedly in various Islamic and Arab family laws, such as those in Yemen, Kuwait and Syria. All of them state in their first article that marriage is a legal union or a contract that gives the man the legal permission to access his wife sexually. The only time this definition has changed has been in genuine attempts to reform the classic Islamic law on family relations. For example, the Moroccan Family Code of 2004 states, 'Marriage is a legal contract by which a man and a woman mutually consent to unite in a common and enduring conjugal life. ${ }^{\prime 6}$

\section{Common provisions of Islamic Law Regarding Marriage and Divorce}

Aside from the legal definition of marriage, classical Islamic law does not envision marriage and family relations as an equal partnership between man and woman. In the paragraphs below I summarise the common provisions regarding marriage and divorce.

\section{Marriage and its Dissolution}

Age of marriage: A Muslim man or a woman must be of sound mind and must have attained puberty to be considered legally eligible for marriage. In classical Islamic law, puberty occurs with the physical signs of maturity such as the emission of semen for boys and menstruation for girls (Büchler and Schlatter, 2013: 37-74).

Guardianship: In contracting a marriage, male guardianship is necessary. The established interpretations of Islamic jurisprudence schools insist that a woman cannot marry without the consent of her male guardian. A guardian handles all kinds of affairs for both his male and female wards, including contracting marriage. When the ward is a male, the guardianship ceases when the boy reaches puberty. For a girl, however, a guardian has the power to impose a marriage on a virgin girl without her knowledge or consent (Manea, 2009: 34). If she contracts a marriage without her guardian's consent, the marriage is not valid. If she was divorced, her consent, in addition to that of the guardian, is necessary to contract the marriage.

The one crucial exception to this rule in Sunni Islam occurs in the Hanafite school of jurisprudence; it is also present in Shi'a jurisprudence. Guardianship is required when the girl is not of age, that is, has not yet reached puberty. But once she reaches puberty, she is allowed to contract her marriage without her guardian's consent. ${ }^{7}$ However, under Hanafite jurisprudence, if the guardian is not satisfied with her choice of husband, he has the right to demand that marriage be annulled on the basis of lack of kafaa: social equality. The concept of kafaa, literally suitability, gives the guardian the right to dissolve and annul a marriage, if he considers the groom/husband not to be fit or suitable.

Polygamy: A Muslim man may be married up to four wives at the same time but a Muslim woman

\footnotetext{
${ }^{6}$ Yemen's Family Law No. 20, 1992 states in Article 1: "Marriage is a union between the couple by a legal charter; it gives the man legal permission to access the woman (sexually), and together they establish a family based on good companionship". Kuwaiti Personal Status Law, No. 51, 1984, states in Article 1: "Marriage is a contract between a man and a woman. [With it] a woman becomes legally (sexually) accessible to the man; and its aim is settlement, chastity, and the strength of the nation". The Syrian Islamic Personal Status Law, No. 59, 1953, says in Article 1: "Marriage is a contract between a man and a woman. [With it] a woman becomes legally accessible to the man (sexually); and its aim is building a mutual life bond and children". This perception of marriage does change, however, when the Islamic law is reformed as with the case of the reformed Moroccan Family Code (Moudawana) of 2004, which states in Article 4 that "Marriage is a legal contract by which a man and a woman mutually consent to unite in a common and enduring conjugal life. Its purpose is fidelity, virtue and the creation of a stable family, under the supervision of both spouses according to the provisions of this Moudawana".
}

${ }^{7}$ Some of the Twelver Shi'a jurists added the condition that for a woman to enjoy this right, she should previously have been married. For more details on the jurisprudences positions on guardianship see Hallaq, 2007: $274-276$. 
can only be married to one man at a time. A Muslim man may marry a Christian or a Jewish woman, but a Muslim woman may not marry a non-Muslim man.

Divorce: A Muslim man may divorce his wife, or any of his wives, by unilateral repudiation, talaq, without having to give any reasons or justify his action to any person or authority. When he divorces his wife by uttering the word three times, the divorce is considered irrevocable: bain. In order to return to him, she must first marry a different man and get a divorce from the new husband.

A Muslim woman can obtain a divorce in three ways: a) by gaining the consent of her husband; $b$ ) by getting a judicial decree for limited specific grounds/harms; or 3) by khula. This means a divorce sanctioned by a judge, but she must give up her financial rights to gain it.

A woman divorced by her husband must observe a waiting period (iddah), normally lasting three months. During this period she cannot marry another man.

A divorce in which the word is uttered fewer than three times is revocable (raji i $i$ ). So even if a woman gets a divorce, her husband may change his mind. During the waiting period, he has the right to return her to his household against her will and he need not sign another marriage contract. One reference on fiqh explained this rule this way: "until the period of iddah has elapsed, the repudiation is revocable (raji'i), and the husband may resume conjugal relations with his wife, if he be so inclined, by a revocation of the repudiation. This he can do whether she be willing or not" (Shukri, 1996: 97).

Obedience, Maintenance, and Beating: Obedience is considered a duty of the wife. A wife should be obedient to her husband insofar as his commands are legally allowed and are ordained as duties of marriage. If a wife is disobedient, she loses her right to maintenance. According to Hanafi jurisprudence, a wife is considered disobedient if she leaves their home without the consent of her husband or without a lawful excuse. Other schools of jurisprudence, however, say that even if she stays at home, she will not be entitled to maintenance if she refuses sexual intercourse (Shukri, 1996: 81; Pearl, 1979: 65). A husband may beat his wife if she is disobedient. The husband can resort to several measures when his wife disobeys him, the last of which is the most severe: beating her. If the woman obeys him, then he should stop using these measures (Manea, 2009: 141-143).

Maintenance after Divorce: Maintenance for a divorced wife ceases after the iddah period, the 3month waiting period after the divorce.

After a divorce, the wife is only entitled to the sum of money set in the marriage contract: the muakhar.

Custody of Children: After a divorce, the custody of a child is entrusted to either the mother or father, depending on the child's age and sex. Younger children tend to be placed in the mother's care and the father takes over custody when the child reaches a given age. However, shari'a makes a distinction between custody and guardianship: the father is the guardian of the child after separation even if the mother is granted the right to custody up to a certain age, after which custody reverts to the father (Mallat, 2007: 357).

If the mother decides to remarry she automatically loses her right to custody. 


\section{Inheritance Law and Testimony}

Inheritance: A Muslim woman receives less than the share of a Muslim man when both parties have an equal degree of relationship to the deceased person. Hence, a sister inherits from her father half of what her brother inherits. A Muslim husband inherits half of what his wife leaves, provided that she did not have a son. If she does, then the husband inherits a quarter. A Muslim wife inherits a quarter of her husband's estate if he has no son. If he has a son, then she inherits an eighth (Abu Zahra, 1963: 122, 131; An-Na'im, 1990: 176).

Being of a different religion is a total bar to inheritance. Thus a Muslim may neither inherit from, nor leave an inheritance to, a non-Muslim (An-Na'im, 1990: 176).

Testimony: The testimony of two women equals that of one man. Originally this rule was meant for financial affairs; but the jurists expanded the rule and made it a general rule.

These discriminatory provisions are not theoretical. They shape the perception of women's rights in Islamic charters on human rights. In fact Article 6 of the Cairo Declaration on Human Rights in Islam reflects the classical Islamic view of law in a literal sense. A woman is equal to a man in human dignity but not in human rights. She has her own civil entity and financial independence and the husband is responsible for her maintenance. Yet this financial responsibility of the husband is inherently connected to the wife's obedience.

By the same token, the practice of letting theological interpretations influence decisions on family affairs takes two forms in the Arab MENA region. First, some countries, including Egypt, Bahrain, Lebanon, Qatar and Saudi Arabia, have no unified personal status code, so the issue is left entirely to the judiciary, "which is heavily influenced by the conservative nature of classical Islamic jurisprudence" ${ }^{\prime \prime}$.

In Egypt, for example, several personal status laws exist, some dating back to the 1920s. However, in cases where the law contains no textual provision, recourse is made to the established views of the Sunni Hanafi school of jurisprudence. Rulings made in accordance with those views could contradict the spirit of the current era and human rights. One famous example is the 1995 ruling, upheld by the Court of Cassation or Supreme Court, ordering the Egyptian scholar Nasr Hamid Abu Zaid to divorce his wife, against his will or hers, on the ground that he committed apostasy in some of his books. The court based its ruling on the Hanafi opinion that a heretic must be divorced from his wife. ${ }^{9}$

Second, other Arab states, including Jordan, Algeria, Kuwait, Yemen and Syria, have codified provisions of Islamic jurisprudence into a unified law that applies to Muslims.

Family laws may be less discriminatory in some Arab countries than in others. As a rule, personal status laws in North Africa are more progressive than those in the Arab Middle East. In fact, Tunisia, and to a lesser extent Morocco, stand as examples of how such laws can be reformed in a way that mostly reflects the concept of gender equality.

Notwithstanding the above, certain characteristics are common to family law in all Arab states, with Tunisia and Morocco again the exceptions. These include the notion that men are women's keepers and have a degree of command over their lives. This notion has been translated into several laws that are relevant here: laws obliging husbands to support their wives financially while commanding their wives to obey them, laws that grant men alone the right to unilaterally divorce their wives and the right to require their return in the event of revocable divorce, and laws

\footnotetext{
${ }^{8}$ United Nations Development Program, Arab Human Development Report 2005 (2006): "Towards the Rise of Women in the Arab World', New York, United Nations Publications, p. 189, quoted in Manea, 2011: 6.

${ }^{9}$ UNDP, quoted in Ibid.
} 
restricting women's ability to marry, move, work or travel freely without the consent of their male relatives or husbands. ${ }^{10}$

Hence, a woman may have the right to be elected to parliament or be chosen as a minister in a Arab government cabinet, yet this very parliamentarian or minister may not be allowed to travel outside the country with a government delegation if her husband withholds his permission. If you think this situation is only theoretically possible, think again. A female Arab minister mentioned it to me during an interview.

It should be mentioned at this point that the family laws of Islamic states differ in the minimum age of marriage. Some countries with codified systems legislate minimum ages for marriage and set restrictions on child marriage. ${ }^{11}$ For example, in Bangladesh, Tunisia, Algeria and Morocco the minimum age for girls is set at 18 . Other countries set a very low minimum age or none at all. In Syria, that age is 15, in Iran 13, in Sudan 10. And in Yemen and Saudi Arabia there is no minimum age for marriage.

In addition, some of the laws that set a minimum age of 18 are full of loopholes and the provisions are rarely accessed. The weaknesses in the law and its implementation often result in a wide gap between the legal minimum age of marriage and the minimum age practised in communities. Hence, some families take advantage of the loopholes that give judges leeway to allow underage girls to marry at the request of their guardians. And other families bypass the law by arranging a religious marriage ceremony for their underage daughter and then wait until she is 18 to officially register the marriage. If the marriage is not registered and the husband decides to leave, the child bride is left without any legal protection for herself and her children (WLUML, 2006; Roudi-Famimi and Ibrahim, 2013). This situation does not only occur in Egypt or Jordan. It happens in Britain as well.

\section{Application of Islamic Law in Sharia Councils and Muslim Arbitration Councils}

Which brings me to the question: What type of Islamic law is being implemented within Britain's shari'a courts? The short answer is: the classical Islamic law with all its contradictions and discrimination.

The five "judges" I interviewed who are involved with these tribunals stated that they rely on one of the four classical types of Sunni jurisprudence. The Muslim Arbitration Tribunal uses the Hanafi jurisprudence by default, but does refer to the others at times. When a person of Shi'a background comes to them, they apply the Shi'a jurisprudence on her/his case.

To them, what they are applying is not only figh, the jurists' traditions. They are applying what they think of literally as God's Law, the law of Allah. Hence, depending on the type of shari'a court applying this law, it can either seek a fundamentalist interpretation of figh, or it can try to make the lives of women easier by seeking the most lenient interpretation. But the mindset is framed by the perception that shari'a is God's law and therefore better than any other secular law. The mindset is also shaped by the acceptance of the rules I mentioned above, that regulate marriage, divorce, polygamy, guardianship, inheritance, etc., anything related to family affairs and women's

\footnotetext{
${ }^{10}$ UNDP, quoted in Ibid., pp. 6-7.

${ }^{11}$ For more information see Women Living Under Muslim Laws (WLUML), 2006; and Roudi-Fahimi and Ibrahimi, 2013: 1-7.
} 
position within the family. They accept these rules and do not question them. Hence during my interviews with the five "judges", including the female judge, they reflected their perception that this is what Islam commands, this is what God commands, and we are following God's law.

Those interviewed are not interested in considering modern ijtihad, rational independent juristic reasoning. If you bring up examples of it, like Abdullahi Ahmed An-Na'im, the well-known Muslim scholar who studies human rights and Islamic law, or the Moroccan Family Code of 2004, which used ijtihad as a means to reform family law in a way that would integrate gender equality, or if you allude to the evolutionary nature of fiqh, the doctrinal traditions developed by jurists over centuries, their reaction would be a polite rebuff. Or it might be a clear-cut answer like this one from Sheikh Faizul Aqtab Siddiqi, the director of the Muslim Arbitration Council ${ }^{12}$ :

Sheikh Siddiqi: I do not disagree with the idea of ijtihad and qiyas [independent juristic reasoning and one of its techniques and analogies]. This is our forte. We have to do ijtihad. But no ijtihad can cancel the direct rule of God, the hukum of Allah. This is not possible. There cannot be any evolution of the direct rules, ahkam. For example, the rule of corporal punishment - cutting off the hands - hukum of had - can be suspended due to certain social circumstances, but cannot be terminated as barbaric or irrelevant to modern society. I do not think so. I am a firm believer in corporal punishment, hudud, but in the right social environment.

\section{Manea: And what is the right social environment?}

Sheikh Siddiqi: Equal distribution of wealth, there is full education within the community, there are the people who are believers, momeneen, people who are living according to true belief in Allah and they are leading their lives to please Allah. In those circumstances, where they have no excuse whatsoever but to accept the rules of Shari'a, hukum al shariah, then in those circumstances, if there is a transgression then I believe the corporal punishments, hudud, should be implemented.

Within this mindset, the jurists' traditions somehow seem to become sacred in these judges' minds; they reflect a 'divine wisdom' that transcends our understanding. Naturally this leads them to apply the classical Islamic law to the letter, picking and choosing as they want from within that pool of traditions.

Consider the issue of the proper age for marriage. Sheikh Siddiqi of the Muslim Arbitration Tribunal is clear regarding this issue ${ }^{13}$ :

Sheikh Siddiqi: In my view, puberty is the right age. But puberty is the minimum age; then the next criterion is the decision of the guardian, he has to make the decision. Because in some societies, 12- or 13-year-old women, girls, they are more or less fully fledged women, they are fully functional, and you in Western societies, [...] are having babies, they are having sex, so they are fully grown and fully mature; there are some 12-year-olds that are not in that condition, they are very weak, they are not fully functional as women, and they do not want to get married. So it is the job of the wali, the guardian, to ensure that the girl is protected and the girl is not subjected to a marriage in this situation where her personal circumstances do not allow this marriage to take place.

Again, we see classical Islamic jurisprudence being used as a point of reference in these courts.

The guardianship issue clearly illustrates this point. As we saw above, Sheikh Siddiqi considers that the guardian knows best for his ward. Dr Mohammad Shahoot Kharfan, of the Muslim Welfare House, demands that the bride and the groom and the guardian be present at the wedding ceremony. But to contract the marriage, the guardian has to approve. One example he gave me

\footnotetext{
12 Sheikh Siddiqi, Faizul Aqtab(15 January 2013), Director of Muslim Arbitration Tribunal, Interview by author. Nuneaton.

${ }^{13}$ Ibid.
} 
was of a woman in her thirties who wanted to marry. Dr Kharfan asked for her guardian to contract the marriage. When she told him he lives in another country, he called him to get his approval and to ask him to delegate his right of guardianship to another person, a male of course. When I asked Dr Kharfan if her voice was not enough, his answer was matter-of-fact: "the guardian is present, the guardian is present" ${ }^{14}$, meaning, we have a guardian here, and he will decide.

By the same token, Hanafi jurisprudence allows the guardian to annul the marriage of his female ward if he is not satisfied with her choice of the groom, and the people I interviewed consider this provision valid. In fact, it has been used and applied in the Islamic Shari'a Council, Leyton, and the Birmingham Islamic Shari'a Council of the Central Mosque. As I said before, the latter is considered to be supportive of women's needs.

The following transcript of the interview I conducted with Sheikh Suhaib Hasan, of the ISC in Leyton, exemplifies what I mean about a mindset that leads people to apply the classical Islamic law to the letter, picking and choosing as one likes from within a pool of outdated traditions.

I asked whether he requires the permission of the guardian for a marriage, and he answered this way ${ }^{15}$ :

Sheikh Hasan: You see this is the beauty of this council that you have all forms of ideas [schools of jurisprudence], and we try to pick the idea which is more acceptable and more appropriate for the Muslim masses living in this country [...] When it comes to the guardian, wali, we know that most of the people here come from India and Pakistan and most of the Muslim community is from a Hanafi background. And in Hanafi jurisprudence, they allow an adult woman to conduct her marriage without the knowledge of her wali [the guardian]. But one thing [...] that people do not know [is] that the guardian, the wali, is allowed to ask for faskh, the invalidation [dissolution] of the marriage on two grounds: one, that this woman has married someone who is not equal to her status, that is kuuf', suitable, [kafaa].... The second [is if] she has accepted a dower amount which is far less than the dower amount accepted in her house. For example, her sister got 500 pounds, her cousin got 500 pounds, and she only accepted 10 pounds, so the guardian has the right to go to the judge - qadi - and say, 'I challenge this marriage on one of these two grounds.' So he can invalidate this marriage.

Manea: But have you encountered such cases?

Sheikh Hasan: Many.

Manea: Really?

Sheikh Hasan: Yes, yes. But [suppose] the man is coming from a Shafii [jurisprudence] background, [then] there is no problem, because the Shafii, they say, there is no nikah [marriage contract] without a guardian, wali, and a witness, the Shafii believe in that, the Hanbali and Maliki [jurisprudences] believe in that. [Then,] if they are coming from this

\footnotetext{
${ }^{14}$ Dr Kharfan, Mohammad Shahoot (22 January 2013), Imam Muslim Welfare House, Interview by author, London.

15 Sheikh Dr Hasan, Suhaib (28 January 2013), Founding Member of Islamic Sharia Council, interview by author, Leyton, London.
} 
background and they are saying this marriage was conducted without a guardian, wali, then there is no problem to invalidate it, easy. So we can invalidate it easily.

Manea: But have you really had a case where the father said, I don't accept the marriage of my daughter?

Sheikh Hasan: Yes. We had [such a] case. And [the father] strongly contested [his daughter choosing her own husband] [...] If the woman is also ready to invalidate the marriage, then it is no problem. You [just] say your father is asking and you are willing. The problem is that [this woman] does not want to invalidate [her marriage] and she is attached to this boy and the father is asking for the invalidation of this marriage. We told the father, you have these two grounds; if you can prove to us that she is married to someone [not] equal to her, [...] or she has accepted a very low dower amount, then we can invalidate it, and we did invalidate some marriages on this ground.

Sheikh Mohammad Talha Bokhari of the Birmingham council does not question the validity of this provision: he says the guardian has the right to invalidate a marriage if the groom is considered unfit. Nonetheless, he says they try to implement this rule in a more 'sensitive' manner - if one can use that adjective. He explained to $\mathrm{me}^{16}$ :

Sheikh Bokhari: [...] the Hanafi jurisprudence gives the right - the haq - to the guardian the wali - to object to the marriage, haq al Kafaa, [...] because she has married a man who was a source of shame for their family. But [this role is only valid] up to [a point]. As a rule, if the girl is not pregnant, kafaa is possible. If the girl has become pregnant then his guardianship has [expired]. This is the Hanafi ideology for this matter. And mostly it is suitable in this situation in this world.

Manea: And have you had cases like this?

Bokhari. Yes.

Manea: Really? Could you give me an example?

Sheikh Bokhari: For example, a lady came; she was nearly 29 and she found someone and that person has become Muslim. The husband was not born Muslim. She was from Somali and the husband was from Ghana. The father was not happy with that [because the husband was from Ghana] and objected to this marriage. And [we asked him] why have you objected. Because he is Muslim, thank God, and according to Islam he has all the rights that a Muslim has. He [the father] said 'but he is from Ghana, I do not like it.' I said this not legal; [the father's position] is not a matter of Islam, because Islam says all [Muslims] are equal. He is a Muslim. Because he is doing a very good job as a bank manager and she was very happy, the father said ok. [...] And she has become pregnant. And we said your objection is annulled. You have lost your right to kafaa and guardianship [because of her pregnancy].

\section{Conclusions}

It is a mindset - a mindset that does not belong to the twenty-first century. A mindset that does not see harm in beating a wife. It is how one is beating his wife that seems to be under question: one should not harm the woman by hitting her on the face, nor should he leave marks on her body. In fact, if one follows the 'correct' example of the Prophet, one should use toothpicks to hit her: 'How much will she get hurt from the toothpick (miswak)?' Or 'you can make a knot in her scarf' and hit her with it: 'How much can a person feel from that?' For the main purpose of beating

\footnotetext{
${ }^{16}$ Sheikh Bokhari, Mohammad Talha (23 January 2013), Islamic Shari'a Council of the Central Mosque, Interview by author, Birmingham.
} 
is to hurt her feelings, not her body. ${ }^{17}$ Of course, if the husband beats her 'savagely' then that is a ground for divorce.

Consistency in logic is not a feature of this mindset or these outdated laws.

When a law tells us that the rights of a child or a woman are irrelevant, that it is 'ok' to force a child or woman to marry, or to simply ignore her choice and wish to remain married and annul her marriage because her guardian has a legal right to do so, when a law tells us that man and woman are not equal in dignity and rights, when a law makes it possible to violate a woman's dignity and strip her of her equal rights, then it is incumbent on us to take a difficult step and make a judgement: these are bad laws by today's standards. They have no place in a modern society. It is our duty to make that judgement.

Cultural relativism cannot justify a child marriage, cannot justify forcing a woman to marry and cannot justify beating a wife. Doing so is a matter of domestic violence in any language. Using Islamic jargon will not make it tolerable. Using a culturally relativist argument about group rights or religious rights to justify the application of such rules is not only shameful. It is outrageous.

Women and men in Islamic countries have been fighting to change and modernise these laws. Yet, to the essentialists, their struggle seems irrelevant, inconsequential. The essentialists would prefer to bring in a religious law, snatched out of its medieval social and historical and geographical contexts, and apply it today in the middle of Britain. They think they are protecting "Muslims' rights". After all, that is what the 'Muslims' want. Well, perhaps it is time to ask this question: Who is speaking in the name of Muslims, and whose rights will be protected here?

Given this discrepancy, you might understand why I have little sympathy for the voices calling for the introduction of Islamic law in family affairs in European and North American societies. It is the consequences of such calls that one should examine to understand how dangerous they could be to concepts of gender equality and women's and children's rights. In fact, these voices are actually calling for the legitimization of systematic discrimination against women and children. And such discrimination will certainly not help any successful integration of migrants' communities of Islamic faith. Indeed, it will only lead to the cementation of closed parallel societies, with two types of women, Western women who enjoy their rights according to the state's laws, and migrants' women who do not.

\section{References}

Imam ABU ZAHRAH, Mohammad (1963): Ahkam Al Tirkat wa al Mawari'ith - Provisions for Legacies and Inheritances, in Arabic, Beirut, Dar Al Fikr Al Arabi.

AN-NA'IM, Abdullahi Ahmed (1990): Toward an Islamic Reformation: Civil Liberties, Human Rights, and International Law, Syracuse, NY, Syracuse University Press.

BANO, Samia (2012): Muslim Women and Shari'ah Councils: Transcending the Boundaries of Community and Law, London, Palgrave Macmillan.

BROWN, Colin: "Let us adopt Islamic family law to curb extremists, Muslims tell Kelly", The Independent, 15 August 2006. Available at: http://www.independent.co.uk/news/uk/politics/let-

${ }^{17}$ Sheikh Bokhari, Mohammad Talha, interview by author, ibid. 
us-adopt-islamic-family-law-to-curb-extremists-muslims-tell-kelly-411954.html [Accessed: 15 July 2015].

BÜCHLER, Andrea and SCHLATTER, Christina (2013): "Marriage age in Islamic and contemporary Muslim family laws: A comparative survey", Electronic Journal of Islamic and Middle Eastern Law, vol. 1, pp. 37-74.

DONNELLY, Jack (Nov. 1984): "Cultural relativism and universal human rights", Human Rights Quarterly, vi/4, p. 400-419, https://doi.org/10.2307/762182.

DUPRET, Baudoiun; BERGER, Maurits and AL-ZWAINI, Laila (eds) (1999): Legal Pluralism in the Arab World, The Hague, Kluwer Law International.

EMON, Anver M (2012): Religious Pluralism and Islamic Law: Dhimmis and Others in the Empire of Law, Oxford, Oxford University Press, https://doi.org/10.1093/acprof:oso/9780199661633.001.0001.

GRIFFITHS, John (1986): “What is Legal Pluralism?”, Journal of Legal Pluralism, vol. 32, nr. 24, pp.151, https://doi.org/10.1080/07329113.1986.10756387.

GRILLO, Ralph et al (eds) (2009): Legal Practice and Cultural Diversity, Surrey, Ashgate.

HALLAQ, Wael B. (2007): Shari'a: Theory, Practice and Transformations, Cambridge, Cambridge University Press.

KEMPER, Michael and REINKOWSKI, Maurus (eds.) (2005): Rechtspluralismus in der islamischen Welt: Gewohnheitsrecht zwischen Staat und Gesellschaft, Berlin, Walter de Gruyter, https://doi.org/10.1515/9783110910483.

KHADDURI, Majid (Jan. 1946): "Human rights in Islam", Annals of the American Academy of Political and Social Science, vol. 243, pp. 77-81, https://doi.org/10.1177/000271624624300115.

MALLAT, Chibli (2007): Introduction to Middle Eastern Law, Oxford, Oxford University Press, https://doi.org/10.1093/acprof:oso/9780199230495.001.0001.

MANEA, Elham (2016): Women and Sharia Law: The Impact of Legal Pluralism in the UK, London, I.B. Tauris, https://doi.org/10.5040/9781350989825.

MANEA, Elham (2011): The Arab State and Women's Rights: The Trap of Authoritarian Governance, London, Routledge, https://doi.org/10.4324/9780203807583.

MANEA, Elham (2009): Ich will nicht mehr schweigen: Der Islam, der Westen und die Menschenrechte, Freiburg, Herder Verlag.

PEARL, David (1979): A Textbook on Muslim Law, London, Croom Helm.

ROUDI-FAHMI, Farzaneh and IBRAHIM, Shaimaa (2013): Ending Child Marriage in the Arab Region, Washington, DC, Population Reference Bureau.

Sezgin, Yüksel (2004): "Theorizing Formal Pluralism: Quantification of Legal Pluralism for Spatio Temporal Analysis", The Journal of Legal Pluralism and Unofficial Law, 36:50, 101-118, https://doi.org/10.1080/07329113.2004.10756580.

SHUKRI, Ahmed (1996): Muhammedan Law of Marriage and Divorce, New York, Ams Press.

UNITED NATIONS DEVELOPMENT PROGRAM, Arab Human Development Report 2005 (2006):

"Towards the Rise of Women in the Arab World", New York, United Nations Publications.

WOMEN LIVING UNDER MUSLIM LAWS (WLUML) (2006): “Knowing our Rights”, Women, Family, Laws and Customs in the Muslim World, London, WLUML. 
YILMAZ, Ihsan (2005): Muslim Laws, Politics and Society in Modern Nation States: Dynamic Legal Pluralism in England, Turkey and Pakistan, Farnham, Surrey, Ashgate Publishing.

YILMAZ, Ihsan (April 2002): "The challenge of post-modern legality and Muslim legal pluralism in England", Journal of Ethnic and Migration Studies xxvii/2, pp. 343354,https://doi.org/10.1080/13691830220124378.

\section{LAWS}

Kuwaiti Personal Status Law, No. 51, 1984

Moroccan Family Code (Moudawana) of 2004

Syrian Islamic Personal Status Law, No. 59, 1953

Yemen's Family Law No. 20, 1992

\section{INTERVIEWS}

Sheikh BOKHARI, Mohammad Talha (23 January 2013), Islamic Shari'a Council of the Central Mosque, Birmingham.

Sheikh Dr HASAN, Suhaib (28 January 2013), Founding Member of Islamic Sharia Council, Leyton, London.

Dr. KHARFAN, Mohammad Shahoot (22 January 2013), Imam Muslim Welfare House, London.

Sheikh SIDDIQI, Faizul Aqtab (15 January 2013), Director of Muslim Arbitration Tribunal, Interview by author. Nuneaton. 